\title{
Pembentukan Citra Politik di Media Sosial Twitter
}

\author{
Rahayu Ramadani ${ }^{1}$, Mifda Hilmiyah ${ }^{2}$ \\ IAIN Parepare \\ e-mail: mifdahilmiyah@iainpare.ac.id
}

\begin{abstract}
Abstrak
Media sosial adalah sebuah bentuk dari media massa yang berbentuk online dimana para penggunanya dapat dengan mudah berinteraksi dengan menciptakan informasi melalui blog, wiki, dan dunia virtual lainnya. Penelitian ini menggunakan teori eksistensi diri dan teori spiral kesunyian. Salah satu media sosial yang populer di kalangan masyarakat adalah Twitter. Twitter merupakan layanan jejaring media sosial yang memberi akses penggunaan untuk mengirim, membaca dan membalas pesan berbasis teks, gambar dan video dengan batas teks hingga 280 karakter. Twitter menjadi salah satu media sosial yang digunakan petinggi politik untuk berinteraksi dengan pendukungnya dan menarik empati masyarakat. Dalam agendanya, tokoh politik akan lebih sering memperbaruhi Twitternya saat mendekati pemilihan umum atau saat terjadi isu-isu besar. Media sosial memiliki hubungan yang erat dengan politik karena media sosial khususnya Twitter memiliki saluran yang dekat dengan masyarakat sehingga masyarakat mudah memperoleh pemberitaan secara langsung dari para tokoh politik.
\end{abstract}

Kata Kunci: Twitter, Citra Politik, Media Sosial

\begin{abstract}
Social media is a form of online mass media where users can easily interact by creating information through blogs, wikis, and other virtual worlds. This research uses the theory of self existence and the theory of the spiral of silence. One of the most popular social media in the community is Twitter. Twitter is a social media networking service that gives access to the use of sending, reading and replying to text, image and video based messages with a text limit of up to 280 characters. Twitter is one of the social media that political leaders use to interact with their supporters and attract public empathy. In its agenda, political figures will more often update Twitter as they approach elections or when major issues occur. Social media has a close relationship with politics because social media, especially Twitter, has channels that are close to the community so that people can easily get news directly from political figures.
\end{abstract}

Keywords: Twitter, Political Imagery, Social Media 


\section{PENDAHULUAN}

Komunikasi merupakan proses yang dinamis dimana proses tersebut secara konstan berubah sesuai dengan situasi yang berlaku. Sedangakan Shacter menjelaskan bahwa komunikasi merupakkan mekanisme untuk melaksanakan kekuasaan. Dalam komunikasi di area politik ada sebutan komunikasi politik yang artinya yaitu pembicaraan untuk mempengaruhi dalam ketetapan negara. Komunikasi politik juga dapat dikatakan seni desain yang dapat mengubah sesuatu berbau politik yang tidak mungkin menjadi mungkin.

Komunikasi menjadi faktor penting bagi tokoh politik dalam mengundang maupun mempertahankan citra politik mereka dihadapan masyarakat. Proses pembentukan citra politik dapat terjadi di semua jenis media. Selain berkomunikasi melalui acara TV, komunikasi politikus akan lebih efektif jika langsung dapat mendapatkan timbal balik dari masyarakat dimana hal itu hanya dapat diperoleh melalui media sosial. Dalam pemilihan umum bulan April 2019 kemarin, Twitter menjadi akses komunikasi yang paling sering digunakan paslon dalam menarik empati dan simpati masyarakat. Misalnya, Presiden Joko Widodo saja saat masa kampanye dapat berkicau 5 kali bahkan lebih di Twitter dalam sehari.

Sumber Kompas.com menyebutkan bahwa pada laporan finansial Twitter kuartal ke-3 tahun 2019, pengguna aktif harian di platform Twitter dicatat meningkat 17 persen, ke angka 145 juta pengguna. Uniknya, Indonesia diklaim menjadi salah satu negara yang pertumbuhan pengguna aktif harian Twitter-nya paling besar.

\section{PEMBAHASAN}

Politik dapat diibaratkan sebagai arena bertarung yang dalam penanganannya membutuhkan strategi jitu. Di era sekarang tidak dibutuhkan lagi politik uang dalam memenangi hati rakyat, saat ini rakyat lebih memusatkan perhatian kepada tokoh politik yang dapat membawa bangsa dan negara untuk mencapai kemajuan. Berdasarkan dari survey tahun 1997-1998 oleh Pew Research Center for the People and the Press dinyatakan sebuah fakta bahwa 
faktor utama penentu kemenangan pemilu adalah kualitas pesan kampanye dan strategi pencitraan para pemimpin politik.

Bagi masyarakat yang melek akan politik, pemaparan strategi program kerja sudah sangat cukup untuk mengetahui bagaimana politikus dan partainya. Namun bagi yang buta akan politik, lebih suka melihat bagaimana citra yang dibentuk atau dilakukan oleh politikus dan partainya.

Dalam memahami masalah "Pembentukan Citra Politik di Media Sosial Twitter" dapat dilakukan dengan melakukan pendekatan melalui teori eksistensi dan teori spiral kesunyian.

\section{Teori Eksistensi Diri}

Eksistensialisme secara etimologi yakni berasal dari kata eksistensi, dari bahasa lain existere yang berarti apa yang ada, apa yang memiliki aktualitas, apa saja yanh di alami. Konsep ini menekankan bahwa sesuatu itu ada. Eksistensi manusia dipandang sebagai satu kesatuan yang menyeluruh, yakni sebagai kesatuan individu dua dunianya. Sebagaimana diungkapkan Heidegger (dalam Friedman \& Schustack, 2008) bahwa eksistensi adalah makna dari kebeeradaan manusia yang mengedepankan masalah being-in-the-worlbeing-in-the-world, yaitu diri manusia tidak adakan ada yanpa dunia dan dunia tidak akan ada tanpa makhluk yang mempersepsikannya. Dunia manusia bukan dunia fiksi saja, melainkan dunia makna, yakni pemaknaan individu terhadap dunia. Oleh sebab itu, tidak mungkin bisa memahami manusia tanpa memahami dunia tempat eksistensi manusia misalnya rumah tempat tinggal individu dan tempat dimana ia merasa bermakna sebagai individu, tempat bekerja dimana seseorang mengekspresikan kemapuan dan merasa menjadi manusia, sekolah dimana ia belajar dan mengekspresikan keberadaannya. Melalui dunia inilah makna eksistensi tampak bagi diri sendiri dan orang lain.

Eksistensi manusia adalah suatu eksistensi yang dipilih dalam kebebasan. Bereksistensi berarti muncul dalam suatu perbuatan, yang harus dilakukan setiap orang bagi diriya sendiri. Menurut Kierkegaard bapak eksistensialis menekankan bahwa yang pertama penting bagi manusia yakni keadaanyya sendiri atau 
eksistensinya sendiri. Tetapi Kierkegaard menekankan bahwa eksisitensi manusia bukanlah "ada" yang tatis, melainkan "ada" yang "menjadi". Dalam arti terjadi perpindahan dari kemungkinan menjadi "ke" nyataan. Apa yang semula berada sebagai kemungkinan berubah menjadi kenyataan. Gerak ini adalah perpindahan yang bebas, yang terjadi dalam kebebasan. Hal ini terjadi karena manusia mempunyai kebebasan untuk memilih.

\section{Teori Spiral Kesunyian}

Teori spiral kesunyian (spiral of silence) adalah sebuah teori media yang lebih memberi perhatian kepada pilihan mayoritas dibandingkan pilihan minoritas. Teori ini dikemukakan oleh Elizabeth Noelle-Neumann tahun 1974, dimana oleh para ahli teori ini dikatakan sebagai pembentuk opini publik yang paling berpengaruh (Eriyanto, 2012:13).

Teori spiral kesunyian telah diuji oleh banyak negara untuk membuktikan bahwa apakah teori ini dapat digunakan di semua negara ataukah hanya dapat digunakan di kondisi tertentu saja. Hasil dari berbagai uji dari teori spiral kesunyian yaitu teori ini dapat dilakukan untuk menjelaskan berbagai proses pembentukan opini publik dalam kontkes negara yang berbeda-beda. Teori pembentukan opini publik direlasikan pada pendapat bahwa masyarakat sadar akan isu-isu publik dan selalu was-was akan opini yang beredar di masyarakat dan media.

Teori spiral kesunyian berhubungan dengan apa yang menjadi penyebab terbentuknya pendapat baik itu pendapat umum maupun pendapat pribadi, setelah seseorang mendapatkan informasi dari media massa, dimana dalam riset penelitian ini penulis mengangkat media sosial Twitter. Berdasarkan teori ini, masyarakat secara universal berusaha menghindar dari rasa terisolasi sendirian dengan mempertahankan opinina. Masyarakat tersebut kemudian mengamati lingkungannya dan opini yang berkembang di media, dan mengolah hasil komunikasi intrapersonal yang dilakukannya dengan masyarakat lain tanpa melupakan persepsi pribadinya. 
Hasil dari konfigurasi opini media massa utamanya media sosial, opini intrapersonal, dam presepsi pribadi, maka masyarakat akan memberikan pandangan apa yang bertahan dan paling polpuler, sehingga pandangan itulah yang kemudian menjadi pendapat sekaligu sikap dari individu masyarakat. Semua orang punya kecendrungan konformitas tersendiri, konformitas adalah perasaan yang lebih nyaman jika pendapatnya sama dengan pendapat yang dominan berkembang di mayoritas lingkungan. Karenanya, banyak masyarakat akan mengubah pendapatnya ke pendapat yang mayoritas di lingkungannya karena tidak ingin merasa sendiri.

Titik berat dari teori spiral kesunyian yaitu interaksi intrapersonal dan interaksi sosial. Opini publik yang menjadi isu kontroversial lebih cepat berkembang ketika diangakat oleh media massa khususnya dalam era sekarang yakni media sosial, dan akan lebih cepat lagi apabila isu tersebut disebarkan secara berantai melalui komunikasi intrapersonal. Dari kegiatan tersebut dapat dibuktikan bahwa dalam pembentukan opini telah ada persaingan antara opini yang satu dengan opini lainnya. Dapat disimpulkan, siklus opini masyarakat yaitu, dibentuk, disusun, ditambahkan, dikurangi, lalu kemudian diubah oleh media dan komunikasi intrapersonal.

Dalam teori spiral kesunyian yang dicetuskan oleh Elizabeth Noelle tahun 1984, melalui tulisannya yang berjudul "The Spiral of Silence” dikemukakan bahwa dalam sebuah kelompok masyarakat pendapat mayoritas/dominan akan lebih dipercayai ketimbang pendapat minoritas. Masyarakat yang memiliki opini/pendapat minoritas akan lebih memilih diam dan cenderung tidak mengemukakan pendapatnya kepada individu lain, dan bahkan seperti dikatakan sebelumnya mereka akan lebih memilih untuk mengubah opininya menjadi sama dengan opini mayoritas.

Berdasarkan dari apa yang dijelaskan sebelumnya, pembentukan citra politik di media sosial menjadi sangat lebih mudah dilakukan apabila citra yang kita buat dapat menyentuh masyarakat mayoritas dan membungkam sisi masyarakat yang minoritas. Dalam hal ini, politikus akan lebih sering menyebarkan hal-hal berbau empati untuk menarik dan menggiring opini 
masyarakat berpihak padanya, dimana masyarakat indonesia yang mayoritas penduduknya buta akan politik lebih mempercayai citra yang dibentuk di media sosial.

\section{Media Massa}

Media massa merupakan penghubung dalam melakukan komunikasi yang menjadi alat penyampaian informasi atau pesan kepada masyarakat umum (massa). Media massa contohnya yaitu, surat kabar, radio, televisi, majalah, facebook, twitter, dll yang menjadi sumber informasi masyarakat umum. Media massa terdiri atas media elektronik (televisi dan radio), media cetak (surat kabar, majalah, tabloid), media sosial/cyber (Twitter, Facebook, Internet, dsb).

Media massa juga menjadi sumber informasi mengenai bagaimana citra atau realitas seseorang seperti selebriti atau politikus. Dimana media memberikan nilai-nilai yang dicampurkan dengan berita dan hiburan. Penggunaan media massa sebagai alat kampanye menjadi alat yang sangat dibutuhkan dalam urusan politik masa ini. Efek media massa ke masyarakat umum sangat besar pengaruhnya dalam memberikan opini yang dominan dengan cakupan yang besar dan terbuka untuk umum (Anwar, dkk, 2019:2).

\section{Media Sosial (Twitter)}

Media sosial merupakan perangkat lunak yang meberikan akses bagi individu maupun kelompok untuk berkomunikasi. Media sosial sebagai alat media yang fokus pada eksistensi pengguna yang memfalitasi mereka dalam berkomunikasi dalam bentuk online. Pada intinya, media sosial didasari atas tiga hal yakni berbagi, kolaborasi dan hubungan. Sejak tahun 2002 sampai saat ini, banyak muncul berbagai jenis media sosial yang baru dengan berbagai karakter baru dengan kelebihan dan kekurangan masing-masing seperti, Facebook, Twitter, Google, Instagram dan lain sebagainya. Selain sebagai platform komunikasi, media sosial juga dapat sebagai media pemasaran.

Ada beberapa karakteristik dari media sosial secara universal, yaitu ; 
1. Jaringan, adalah alat yang menjadi penghubung antara komputer atau gawai dengan perangkat keras lainnya, ini diperlukan agar komputer dapat melakukan perpindahan data ke media sosial.

2. Informasi, yang menjadi alasan utama banyaknya penggunaan media sosial, karena pada dasarnya media sosial membuat pengelolahan informasi dan konten.

3. Arsip, media sosial dapat sebagai pengarsipan informasi yang tidak akan hilang dan dapat dikuak kembali.

4. Interaksi, media sosial tidak hanya sekedar sebagai alat untuk menambah teman dan kenalan semata, tetapi harus dilaksanakan dengan interaksi apapun.

5. Simulasi sosial, media sosial memeiliki karakter sebagai pengganti interaksi sosial masyarakat namun di dunia virtual.

6. Konten oleh pengguna, media sosial sepenuhnya merupakan milik pengguna apabila telah membuat akun di masing-masing jenis medi ayang ada, dimana pengguna dapat membuat konten dan bahkan menanggapi konten akun lain (Hartini, dkk, 2018:6).

Di dalam riset masalah terkait "Pembentukan Citra Politik" ini penulis lebih menekankan pada media sosial twitter. Twiitter adalah jejaring media sosial yang memberi akses pada penggunanya untuk mengirim dan membalas pesan bebrbasis teks, gambar dan video degan maksimal 280 karakter yang dikenal sebagai 'kicauan'. Hingga januari 2019, diketahui bahwa ada lebih dari 126 juta pengguna yang telah terdaftar di twitter sebagai pengguna aktif. Tingginya popularitas twitter membuat para tokoh masyarakat baik selebriti hingga politikus masing-masing membuat akun (https://tekno.kompas.com).

Secara sederhana, kicauan twitter dapat dilihat secara umum namun bisa berlangganan dengan mengklik fitur 'mengikuti'. Sebagai jejaring media sosial, twitter memegang prinsip 'pengikut'. Jika anda memilih mengikuti akun lain maka kicauan akun tersebut akan muncul secara rutin di beranda akun anda. Ada 
berbagai konten yang dapat ditemukan di twitter. Berdasarkan riset Pear Analytics, urutan konten dari yang paling sering dibahas ada ;

1. Celotehan yang tidak terlalu penting $(40,1 \%)$

2. Percakapan $(37,6 \%)$

3. Retweet $(8,7 \%)$

4. Promosi diri $(5,9 \%)$

5. $\operatorname{Spam}(3,8 \%)$

6. Berita $(3,6 \%)$

Dari riset tersebut dapat dilihat bahwa promosi diri ada di peringkat ke empat. Ini membuktikan bahwa twitter menjadi ladang yang besar untuk mempromosikan diri khususnya bagi para politikus untuk menggiring opini masyarakat dengan membentuk citranya di media sosial dengan baik.

\section{Pembentukan Citra Politik}

Dikutip dari Firmanzah dan Dutton pencitraan politik merupakan sebuah cara yang digunakan politikus dan partai politiknya untuk memberi kesan baik kepada kahalayak. Pencitraan politik yang dimaksud yaitu pencitraan yang dilakukan di media massa, media sosial, media tradisional dan public relation untuk membuat dan memperkuat pesan politiknya sehingga dapat memebentuk opini di masyarakat yang kemudian dapat membuat masyarakat memihaknya dan bahkan memilihnya saat pemilihan umum (Azhar, Anas, 2017:10).

Citra politik merupakan suatu hal yang diyakini dan diharapkan masyarakat sebagai apa yang dikerjakan oleh politikus dan partainya. Fokus utama dari pencitraan politik adalah menarik simpati masyarakat dan membuat masyarakat menjadi rela memilihnya untuk diberi dukungan. Simpati dalam artian disini yaitu diindikasikan sebagai keinginan masyarakat untuk memilih tokoh atau partai politik dengan harapan mereka dapat memenuhi kebutuhan dan kepentingan masyarakat sesuai dengan citra yang dibuatnya.

Pencitraan awalnnya hanya identik dengan kegiatan humas dalam dunia bisnis, namun di era sekarang telah bergeser ke arena politik. Dimana sekarang ini 
tada yang disebut sebagai komunikasi politik yang khusus membahas mengenai bagaiamana pembentukan citra politik yang baik di masyarakat. Citra dibentuk sebagai akumulasi dari tindakan dan perilaku individu.

Di dalam twitter, biasanya politikus akan membagikan kegiatannya saat bertemu dengan masyarakat dengan caption semenyentuh mungkin sembari memaparkan apa yang akan ditindaklanjuti ke depannya terkait visi dan misinya dalam membentuk era yang baru. Masyarakat biasanya akan lebih menerima citra itu apabila disertai dengan foto atau video sang politikus bersama masyarakat miskin atau terbelakang. Citra dapat didefinisikan sebagai representasi masyarakat umum terhadap politikus yang berhubungan dengan aktivitasnya selama melangkah di dunia politik sebagai kesan dan gambaran publik.

Citra politik juga terkait eksistensi diri yang sepenuhnya dapat terbentuk tergantung bagaimana partainya membentuk dan membangun opini masyarakat yang didasarkan pada realitas yang terjadi. Citra politik dibentuk melalui penayangan visual yang kemudian dikomunikasikan melalui media twitter sampai opini itu terbentuk di pikiran masyarakat. Citra sangat dibutuhkan dalam sebuah organisasi dan individu di dalamnya, tidak terkecuali partai politik yang merupakan sebuah kelompok yang terorganisir dimana para anggotanya memiliki tujuan yang sama untuk memperoleh kekuasaan secara konstitusional.

Pencitraan sangat penting bagi politikus untuk mendongkrak popularitasnya hingga dapat memperoleh suara saat pemilihan umum. Citra politik tidak lepas dari skill para aktor politik untuk mempengaruhi pandangan dan opini politik seseorang. Citra politik dapat membantu dalam memahami nilai dan identifikasi peristiwa, gagasan atau tujuan dari politikus tersebut.

Citra yang positif dapat mencuatkan rasa simpatik massa pendukung maupun masyarakat yang masih di golongan putih untuk dapat menjadi pendukungnya. Citra politik dibenttuk berdasarkan dari informasi yang diperoleh baik secara langsung maupun melalui twitter yang menjadi salah satu dari efek komunikasi politik yang ada.

Citra politik berhubungan dengan pembentukan opini publik karena pada dasarnya opini publik dibentuk dari citra politik yang ada. Sedangkan citra politik 
dibentuk oleh wujud konsekuensi kognisi komunikasi politik. Komunikasi secara tidak langsung yakni melalui twitter menimbulkan pendapat dan perilaku tersendiri, dan cenderung lebih mempengaruhi bagaimana masyarakat mengelompokkan citra yang ada terkait lingkungan opini. Pencitraan memiliki empat fase, yaitu;

a. Representasi, citra yang dibentuk merupakan cerminan dari kenyataan yang ada

b. Ideologi, citra memberi pemahaman yang salah atau berbeda mengenai kenyataan

c. Citra dapat menyembunyikan kenyataan, dan menyataakn bahwa tak ada yang real

d. Citra sama sekali tidak berhubungan dengan kenyataan sebernarnya.

Dari empat fase tersebut diketahui bahwa citra merupakan gambaran akan realtias walau tidak selamanya sesuai dengan kenyataan yang ada.

Pencitraan politik sangat penting dalam politik di era informasi digital sekarang ini, dimana citra poltik yang dibangun politikus melalui twitter agaknya bagai magnet yang menjadi penentu opini masyarakat dalam pemilihan. Melalui media massa dan twitter maka berbagai bentuk opini dan pandangan masarakat seakan disulap dan dimanipulasi melalui pencitraan yang dibentuk politikus yang kemudian diterima oleh masyarakat. Membuat politikus merasa makin bergairah untuk membentuk berbagai citra diri, tanpa memperdulikan realitas yang sesungguhnya.

Frank Jefeknis memberi pemikiran bahwa ada lima jenis citra yang digunakan politikus, yaitu;

1. Citra bayangan (mirror image)

Citra bayangan merupaka citra yang palinng melekat dengan para anggota-anggota partai politik karena orang biasanya menilai individu dari citra partai atau organisasi yang diikutinya. Dengan kata lain citra bayangan merupakan citra yang dimiliki dari citra organisasi yang 
disangkutpautkan dengannya. Opini yang dihasilkan dari citra ini sering kali tidak tepat karena orang luar hanya memandang dari organisasi bersangkutan. Positif atau negatifnya citra yang dihasilkan pun tergantung dan serupa dari citra yang dimiliki organisasi yang ada.

2. Citra kekinian (Current Image)

Citra ini merupakan kebalikan dari citra sebelumnya yakni citra bayangan, dimana citra ini merupakan citra yang melekat pada individu yang mempengaruhi citra partai. Sama seperti citra bayangan, opini yang dihasilkan cenderung tidak benar dan negatif tergantunng seberapa banyak informasi yang diperoleh masyarakat.

3. Citra yang diharapkan (wish image)

Citra harapan adalah citra yang diharapkan oleh pelaku pencitraan. Biasanya citra yang dihasilkan dapat diterima lebih baik oleh masyarakat dan lebih menyenangkan dari citra yang direncanakan sebelumnya. citra harapan biassanya dibuat untuk menyongsong sesuatu yang baru yang masih sedikit pengadaan informasinya sehingga masyarakat tergiring untuk memfokuskan opininya pada citra ini.

4. Citra perusahaan (corporate image)

Citra lembaga adalah bagaimana citra partai dalam pandangan masyarakat secara keseluruhan mengenai pelayanannya dan sejarahnya yang sukses, reputasi yang baik, sumpangsinya kepada bangsa dan negara dalam ekonomi maupun sosial.

5. Citra majemuk (multiple image)

Setiap partai tentunya memiliki anggota dan masinng-masing memiliki perrlaku tersendiri sehingga baik secara sengaja maupun tidak perilaku mereka dapat mempengaruhi citra partai. Maka dari itu, untuk menyatukan citra mereka biasanya partai politik memilih untuk mengadakan keseragaman di anggotanya seperti seragam dinas, mobil dan bahkan sombil-simbol kecil yang digunakan serta berbagai hal lainnya yang dapat menyatukan citra mereka dimata masyarakat untuk membentuk opini yang serentak. 


\section{Citra Politik Jokowi di Twitter}

Kemenangan Joko Widodo dalam setiap pemilihan tidak lepas dari peran citra politik yang dibangunnya. Kuatnya citra yang dibangun Jokowi saat pilpres 2014 dan 2019 menjadi faktor penting yang dapat menggiringnya menjadi orang nomor satu di Indonesia. Dalam citra yang dibentuk Jokowi merupakan sosok yang merakyat, suka terjun langsung ke lapangan atau yang disebutnya sebagai ‘blusukan', ramah dan jujur. Citranya tersebut dianggap sebagai karakter khas dari Jokowi yang berbeda dari tokoh politik lainnya. Semua citra yang dibentuk Jokowi kemudian diabadikannya lalu di upload ke twitternya agar dapat memperlihatkan ke masyarakat atau khalayat umum tentang bagaimana dirinya digambarkan sebagai sosok yang diinginkan masyarakat (Haffiar, dkk, 120).

Ha-hal yang diunggah oleh Jokowi di twitter akan segera ditanggapi oleh pendukungnya kemudian di retweet hingga biasanya menjadikan hal tersebut viral. Citra yang diunggahnya di twitter dan diangkat oleh berbagai media kemudian akan dibicarakan secara komunikasi intrapersonal oleh masyarakat hingga dapat menyebarkan opini-opini hingga membentuk opini yang mayoritas mendukungnya. Terbukti saat masa kampanye tahun 2014 dan 2018-2019 lalu, citra jokowi sebagai politikus yang suka blusukan tersohor ke seluruh penjuru negeri dan membuat mata tertuju ke padanya sebagai sosok presiden merakyat yang diinginkan rakyat kecil. Hingga saat itu kata blusukan menjadi kata yang populer dan diikuti oleh politikus lainnya sampai saat ini.

Selain blusukan, citra Jokowi yang sering ia pamerkan di twitter yakni citra pejabat yang akrab dengan anak muda karena kesukaannya pada musik rock dan metal.sebagai komunikator akan citranya, Jokowi dianggap punya sifat yang humble dimana walaupun ia pejabat namun rasanya ia sama seperti rakyat pada umumnya dengan bahasa yang informal dan merakyat.

Untuk meyakinkan masyarakat terkait citra politik seseorang dibutuhkan strategi komunikasi politik yang tepat, dan aktivitas yang dilakukan harus dilaksanakan secara berulang kali. Akhir dari proses pencitraan ini adalah saat citra itu sudah tertanam secara positif di benak masyarakat umum dan mendorong masyarakat untuk memberikan pilhannya kepada sang politikus. Harus digaris 
bawahi bahwa citra politik bukan hanya sekedar ilusi saja, citra politik juga bisa merupakan realitas yang terjadi sebenarnya.

Tidak selamanya citra politik itu akan melekat dan menetap di diri politikus dalam sistem kognitifnya. Citra itu akan mengalami proses dinamisasi dan transformasi seiring dengan bertambahnya informasi dan pengetahuan politik serta tujuan atau apa yang diinginkan khalayak umum. Citra polittik kemudian akan diganti dan disesuaikan seiring dengan pengetahuan khalayak umum khususnya yang buta akan politik.

Dalam twitter, citra politik akan lebih efektif dilakukan. Dengan hannya dibatasi dengan 280 karakter, twitter memberi komunikasi pendek sehingga politikus hanya dapat memberi poin-poin penting saja saat berkicau di twitter. Twitter dinilai dapat menjadi media yang baik digunakan untuk politikus karena dapat memberi informasi dengan banyak orang tanpa ada batasan penerimaan informasi, yang perlu diperhatikan hanya dari siapa informasi itu berasal.

Dalam politik kontemporer, twitter menjadi saluran media massa yang sangat baik dalam melakukan kampanye. Twitter banyak digunakan politkus dengan didukung oleh para simpatisan maupun buzzer untuk menyebarkan pesan politiknya dengan cara menarik perhatian khalayak, membuat percakapan, membangun opini publik yang kemudian akan diviralkan. Apa yang viral atau trending di twitter sering kali diangkat kembali oleh media massa lain baik online maupunn elektronik.

\section{Citra Politik dalam Teori Spiral Kesunyian}

Teori spiral kesunyian (spiral of silence) adalah sebuah teori media yang lebih memberi perhatian kepada pilihan mayoritas dibandingkan pilihan minoritas. Teori ini dikemukakan oleh Elizabeth Noelle-Neumann tahun 1974, dimana oleh para ahli teori ini dikatakan sebagai pembentuk opini publik yang paling berpengaruh. Di dalam teori ini dianggap bahwa opini yang mayoritas akan mempengaruhi opini minoritas.

Dalam kasus citra Joko Widodo, citra yang dibentuknya dapat membuat khalayak umum menyatukan opininya hingga membentuk sebuah kesepakatan 
atau opini umum yang mayoritas mendukungnya. Seperti dikatan sebelumnya, citra Jokowi yang merakyat dan suka blusukan menarik simpati dan empati masyarakat hingga memperoleh banyak suara dan menjadikannya memiliki kekuasaan presiden.

Tentunya, saat kita berada di sebuah tempat atau kelompok yang mayoritas, kita sebagai kelompok yang minoritas akan lebih memilih diam. Dimana, terkadang kelompok minoritas ini akan kalut dan biasanya memilih untuk mengubah opininya ke opini yang mayoritas setelah terpengaruh dengan melalui interaksi komunikasi intrapersonal baik secara langsung maupun online di twitter.

\section{SIMPULAN}

Sebagaimana telah dipaparkan di atas, citra politik dibentuk dari informasi yang telah diterima dari media sosial twitter yang kemudian diangkat ke media massa lainnya baik itu cetak maupun elektronik. Citra politik akan membantu khalayak umum dalam memahami apa yang kita lakukan dalam melaksanakan kegiatan politik, gagasan, dan tujuan kita yang dapat diterima masyarakat secara subjektif. Citra politik akan sangat penting apabila masayarakat umum menganggap bahwa masalah negara akan dapat terselesaikan dengan fisik, sosial, dan psikologis para politisi dan parpolnya, salah satunya melalui media sosial.

\section{DAFTAR PUSTAKA}

Anwar, Putri Azahra, dkk. 2019. Media Massa dan Citra Politik di Indonesia. Makassar : Universitas Muslim Indonesia (pdf diakses pada tanggal 17 November 2019 https://www.researchgate.net/publication/330242325)

Azhar, Anang Anas. 2017. Pencitraan Politik Erektoral. Yogyakarta : Atap Buku Hartina, Rini, dkk. 2018. Komunikasi dan Media Sosial. Makassar : Universitas Muslim Indonesia. (pdf diakses pada tgl 17 November 2019 17:28; https://www.researchgate.net/publication/329998890)

Haffiar, Hanny dan Rusmulyadi. Dekonstruksi Citra Politik Jokowi dalam Media Sosial. 2018. Jurnal Profesi Humas. UIN Sunan Gunung Djati dan Universitas Padjajaran. Volume 3. h.120-140

https://tekno.kompas.com/read/2019/02/09/11340027/untuk-pertama-kali-twitterungkap-jumlah-pengguna-harian 
Eriyanto. Teori Spiral Kesunyian dan Negara Transisi Demokrasi : Sebuah Pengujian di Indonesia. Jakarta : Jurnal Komunikasi Indonesia. 2012. Volume 1. Nomor 1. ISSN 2301-9816 